\title{
Assessment of post-traumatic PDL cells viability by a novel collagenase assay
}

Pileggi R, DumshaTC, NorJE. Assessment of post-traumatic PDL cell viability by a novel collagenase assay. Dent Traumatol 2002; 18: 186-189. C Blackwell Munksgaard, 2002.

\begin{abstract}
Both length of extra-alveolar time and type of storage media are significant factors that can affect the long-term prognosis for replanted teeth. Numerous studies have examined various media in an attempt to determine the ideal material for storage of the avulsed tooth. The purpose of this study was to compare the number of viable periodontium ligament (PDL) cells in different storage media using a collagenase assay. Thirty-three freshly extracted human teeth were divided into four experimental and two control groups. The positive and negative controls corresponded to $0 \mathrm{~min}$ and an 8-h dry time, respectively. The experimental teeth were stored dry for $30 \mathrm{~min}$ and then immersed in one of four media (Hank's balanced salt solution (HBSS), milk, saline, water) for $45 \mathrm{~min}$. The teeth were then treated with dispase grade II and collagenase for $30 \mathrm{~min}$. The number of viable and nonviable PDL cells was counted with a hemocytometer and analyzed. An ANOva demonstrated no statistically significant differences in the viability of PDL cells among saline, HBSS and milk. Within the parameters of this study, it appears that milk or saline is an equally viable alternative to HBSS for storage of avulsed teeth.
\end{abstract}

\section{Roberta Pileggi', Thomas C. Dumsha, Jacques E. Nor ${ }^{3}$}

'Department of Stomatology/Endodontics, University of Houston Medical Center, Dental Branch, Houston, TX, ${ }^{2}$ Department of Endodontics, University of Maryland Dental School, Baltimore, MD, ${ }^{3}$ Department of Cariology, Restorative Sciences and Endodontics University of Michigan, Dental School, Ann Arbor, MI, USA

Key words: avulsion; collagenase; dental trauma; PDL storage media

Roberta Pileggi, Department of Stomatology/ Endodontics, University of Texas, Health Science Center, 6516 Md Anderson Blvd, Room 202, Houston, TX 77030, USA

Tel:/fax: +1713500 4228

e-mail: roberta.pileggi@uth.tmc.edu

Accepted 9 January, 2002
Traumatic injuries are a common occurrence that require both expedient and informed management by the practitioner. Andreasen and Andreasen (1990) predicted that the incidence of these injuries may eventually surpass theincidence of dental caries (1). Avulsion injury, one of the most severe forms of dental trauma, is characterized by complete displacement of the tooth from its alveolar socket. Due to the complexity of this injury, the neurovascular supply is severely compromised and usually results in a loss of pulpal vitality.

According to Andreasen et al. (3), the factors that play a role in healing of the periodontal ligament (PDL) after avulsion injuries are primarily the amount of physical damage to the root surface and the type of medium in which the exarticulated tooth is stored $(2,3)$. The greatest success of a replanted avulsed tooth occurs when it is immediately replanted, which is not always feasible. Several meth- ods have been suggested to preserve the vitality of the PDL cells. Axhausen (4), suggested placing the tooth under the patient's tongue in cases in which immediate replantation was not possible. However, Dumsha (10), and Patil et al. (18) suggest storing the avulsed tooth in milk, HBSS or saline.

Several techniques have been used to determine the viability of the periodontal cells following avulsion. However, most of the experimental data that is available has been obtained using techniques in which the cells are cultured and/or trypsinized for longer periods of time. Because the extracellular matrix has a high content of collagen and other proteins, it seems reasonable that the use of enzymatic desegregation would provide a greater number of cells within a shorter time frame.

Both collagenase and dispase enzymes disrupt the extracellular matrix and cause the release of cells 
Table1. Analysis of variance

\begin{tabular}{lccccc}
\hline Vitality & Sum of squares & d.f. & Mean square & $F$ & Significant values \\
\hline Between & 23320.34 & 5 & 4664.07 & 80.15 & \\
groups & 1571.16 & 27 & 58.191 & \\
$\begin{array}{l}\text { Within } \\
\text { groups }\end{array}$ & 24891.50 & 32 & & \\
Total & & & & \\
\hline
\end{tabular}

without excessive disruption and destruction of their own membrane. Therefore the use of these two enzymes may provide additional data regarding the viability of PDL cells after avulsion injury. Furthermore, this method may be more representative of the actual clinical situation, because the cells are not subjected to long processing times to determine their viability status.

The purposes of this study were:

1 To investigate the efficacy of a novel and potentially faster method to quantitate the number of viable PDL cells after a simulated avulsion injury.

2 To determine which storage medium maintains the greatest number of viable PDL cells after $30 \mathrm{~min}$ of dry time followed by a 45-min storage period in commonly accepted media.

\section{Material and methods}

Thirty-three freshly extracted caries-free human teeth with normal periodontium and closed apices were used for this study. The extraction was performed as traumatically as possible, by one oral surgery resident. Following extraction, the teeth were held with forceps by the coronal region and the coronal $3 \mathrm{~mm}$ of PDL was scraped with a curette, rinsed with distilled water to remove cells that may have been damaged during extraction. The teeth were divided into six groups after rinsing.

The teeth in the experimental groups were stored dry for $30 \mathrm{~min}$, followed by a 45 -min immersion in one of four experimental media (Hank's balanced salt solution (HBSS), milk, saline, water). The positive control teeth after extraction were immediately treated with dispase and collagenase. The negative control teeth were bench dried for $8 \mathrm{~h}$ followed by treatment in dispase and collagenase.

Each tooth in all the groups was treated separately and incubated for $30 \mathrm{~min}$ in $15 \mathrm{~mL}$ Falcon tubes with a $2.5-\mathrm{mL}$ solution of $0.2 \mu \mathrm{g} / \mathrm{mL}$ of collagenase CLS II (Cooper Biomedical, PA, USA) and a $2.4-\mu \mathrm{g} / \mathrm{mL}$ solution of dispase grade II (Gibco, Taastrup, Denmark) in PBS. The specimens were then centrifuged for $5 \mathrm{~min}$ at 800 r.p.m. and the cells labeled with $0.4 \%$ Trypan Blue (Gibco BRL) for determination of viability according to Polverini and Leibovich (5).

The number of viable and nonviable PDL cells was counted under light microscopy with a hemocytometer and statistically analyzed with an ANOvA and a post hoc Scheffe's Test. An alpha of 0.05 was used for statistical analysis.

\section{Results}

Teeth stored in milk demonstrated the highest number of viable PDL cells followed in rank order by HBSS, saline and water. The analysis of variance demonstrated a significant difference among the groups (Table 1). Table 2 presents the mean and SD of all groups. A post hoc Scheffe's test indicated that water was statistically significantly different than saline, HBSS, milk and both control groups (Fig. 1). The negative control group was statistically significantly

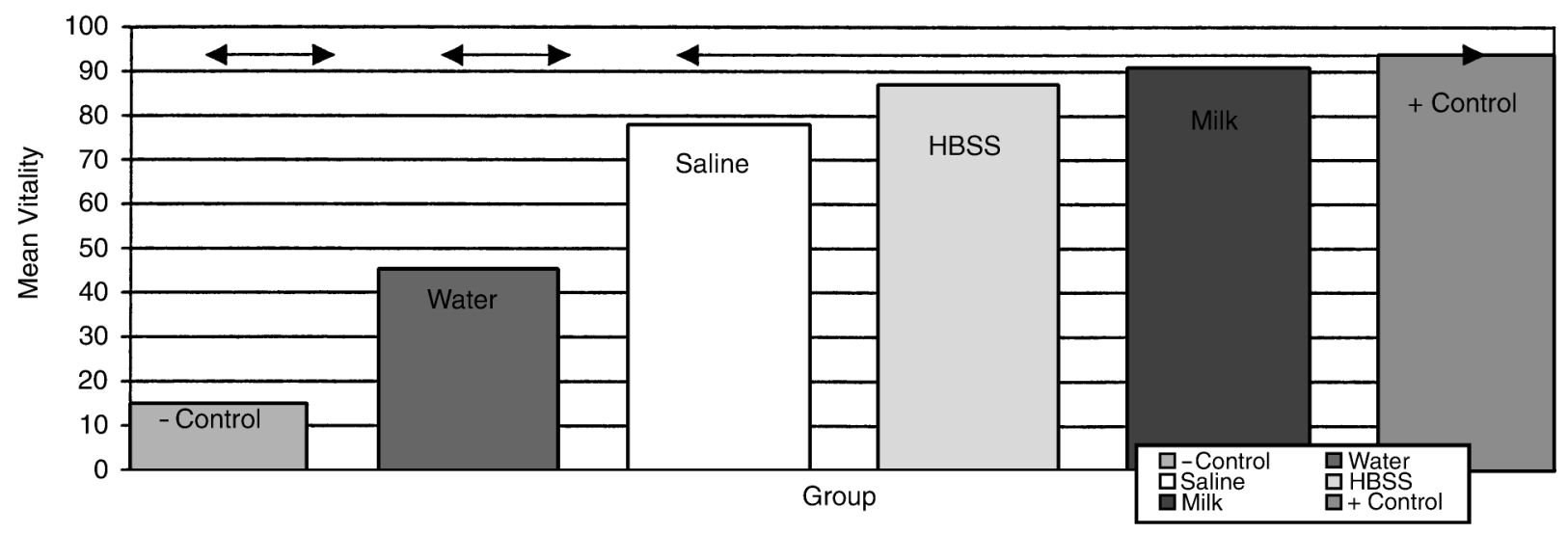

Fig. 1. Mean value of viable cells. 
Table 2. Mean and standard deviation table

\begin{tabular}{lccc}
\hline Groups & Mean & SD & SE \\
\hline Water & 45.17 & 12.03 & 4.54 \\
Saline & 77.80 & 2.92 & 1.19 \\
Milk & 90.59 & 3.77 & 1.53 \\
HBSS & 87.04 & 5.70 & 2.32 \\
+Control & 93.92 & 1.76 & 0.88 \\
-Control & 15.04 & 11.78 & 5.89 \\
\hline
\end{tabular}

different than each of the experimental groups and the positive control group.

\section{Discussion}

Clinical surveys indicate that traumatic dental injuries in children and adolescents are a common problem, and several studies have shown that the prevalence of these injuries is increasing (6). During the 1950s and 1960s, it was reported that more than 2000 teeth were replanted (7).

Long-term prognosis of replanted teeth is dependent in part, upon immediate treatment following injury and PDL cell viability (8-11). Unfortunately, immediate treatment is not always feasible and it has been reported that only one in five children are seen immediately following a traumatic injury (12).

The importance of PDL cell viability prior to replantation was first addressed in 1955, when Hammer demonstrated that the length of survival of a replanted tooth is directly correlated with the amount of viable periodontal membrane (13).

After an avulsed tooth is replanted, the damaged PDL may undergo cell necrosis, macrophage activation, and removal of the necrotic area (8). The activation of osteoclasts may result in inflammatory root resorption. In cases of large areas of damage to the PDL, competitive wound healing begins between cells destined to form bone and PDL-derived cells which formed PDL fibers and cementum. This competition can lead to transient or permanent ankylosis. These sequelae may be minimized if either the appropriate storage media is utilized or immediate replantation is performed.

Numerous studies have attempted to determine which storage media provide the greatest percentage of viable PDL cells in avulsed teeth (13-18). In 1983, Lindskog et al. in an in vivo study with monkeys, compared saliva with milk and concluded that saliva was less suitable than milk due to its low osmolality and higher risk for bacterial contamination (19). Hiltz and Trope demonstrated that Viaspan was the most effective storage medium when compared with milk and HBSS. After $168 \mathrm{~h}$ of storage, 37.6\% of human lip fibroblast stored in Viaspan was still viable (20). However, from a practical standpoint, Viaspan is highly questionable.
In the dental literature, various techniques have been utilized to quantitate the number of viable cells. Reinholdt et al. (1977) used a stepwise trypsinization procedure by exposing samples to trypsin three consecutive times for 20 min each (21). Soder in 1977 utilized chromogenic stain to quantitate viable PDL cells (22). In 1992, Patil et al. used a stepwise trypsinization procedure and fluorescein diacetate as a new staining technique for determining the viability of PDL cells in simulated avulsion injuries (18).

In the current study, to minimize the exposure of cells to active trypsin and to preserve maximum cell viability, the root surface was treated with collagenase and dispase grade II. This procedure allowed rapid cell retrieval and maintained maximum cellular integrity based on the positive control teeth.

The results of this investigation demonstrated no statistically significant difference in the number of viable cells among saline, milk and HBSS after a 30-min dry time. The results of this in vitro study suggest that milk is comparable to both saline and HBSS as a storage media when teeth are stored dry for up to $30 \mathrm{~min}$. This is in agreement with Trope (1995), who suggested that milk is considered the best storage medium when compared with HBSS for uncomplicated avulsion cases due to its practical availability (11).

The fact that saline, milk, and HBSS were comparable with respect to PDL cell viability may be a function of the amount of dry time and/or the storage media. This is also in part supported by the results of Hiltz et al. (20) in that all lip fibroblasts had comparable viability values after 6 h of storage in milk, HBSS, and Viaspan.

Since our study only examined avulsed teeth with 30 min of dry time, further investigations are in progress to determine the consequences of longer periods of dry time with respect to storage media and PDL cell viability.

\section{Conclusions}

1 Within the parameters of this study, it appears that milk is comparable to saline and HBSS for storage of avulsed teeth when dry time does not exceed $30 \mathrm{~min}$.

2 The collagenase and dispase assay appears to be a viable method for evaluating PDL cell viability.

\section{References}

1. Andreasen JO, Andreasen FM. Dental textbook and color atlas of traumatic injuries to the teeth. Copenhagen: Munksgaard; 1994, p. 383-419.

2. Andreasen JO, Borum MK, Loft Jacobsen H, Andreasen FM. Replantation of 400 traumatically avulsed permanent incisors. Part I. Diagnosis of healing complications. Endod Dent Traumatol 1995;11(2):51-8. 
3. Andreasen JO, Borum MK, Andreassen FM. Replantation of 400 traumatically avulsed permanent incisors. Factors related to periodontal ligament healing. Endod Dent Traumatol 1995;11(2):76-89.

4. Axhausen G. Ein Beitrag zur Zahnreplantation. Zahnarztl Welt 1948;3:130-2.

5. Polverini PJ. LeibovichSJ. Induction of neurovascularization in vivo and endothelial proliferation in vitro by tumorassociated macrophages. Laboratory Invest 1984;51(6):63542.

6. Gassner et al. Prevalence of dental trauma in 600 patients with facial injuries. Implications for Prevention Oral Surg, Oral Med, Oral Path Endodon 1999;87(1):27-33.

7. Natiella J, Armitage J, Greene G. The replantation and transplantation of teeth. Oral Surg 1970;71:29-33.

8. Andreasen JO, Andreasen FM. Essentials of Traumatic Injuries to the Teeth: Luxation Injuries. Copyright Denmark, 1990:113-32.

9. DumshaTC, Hovland E. Pulpal prognosis following extrusive luxation injuries in permanent teeth with closed apexes. J Endod, Vol, 1982;8(9):410-2.

10. Dumsha TC. Management of avulsions. Dental Clinics of North America 1992;36:425-37.

11. Trope M. Clinical management of the avulsed tooth. Dent Clin North Am 1995;39(1):93-112.

12. Jarvinen S. Extent to which treatment is sought for children with traumatized permanent anterior teeth. Proc Finn Dent Soc 1979;75:103-6.

13. Hammer H. Replantation and Implantation of teeth. Int Dent J 1955; (5):439-57.
14. Blomlof L, Lindskog S, Hedstrom K-G, Hammastrom L. Vitality of periodontal ligament cells after storage of monkey teeth in milk or saliva. Scand J Dent Res 1980;(88):4415 .

15. Trope M, Yesilsoy C, Koren L, Moshonov J, Friedman S. Replacement resorption after storage of extracted dog teeth in different media. J Dent Res 1992;71:124.

16. Gamson EG, Dumsha TC, Sydiskis R. The effect of drying time on periodontal ligament cell vitality. J Endod 1992;18(4):189.

17. Krasner PR. Treatment of tooth avulsion in the emergency department: appropriate storage and transport media. Am J Emergency Med 1990;8(4):351-5.

18. Patil S, DumshaTC, Sydiskis RJ. Determining periodontal ligament (PDL) cell vitality from exarticulated teeth stored in saline or milk using fluorescein diacetate. Int Endod J 1994;27(1):1-5.

19. Lindskog S, Blomlof L, Hammastrom L. Mitoses and microorganisms in the periodontal membrane after storage in milk or saliva. Scand J Dent Res 1983;91(6):465-72.

20. Hiltz J, Trope M. Vitality of human lip fibroblasts in milk, Hank's balanced salt solution and viaspan storage media. Endod Dent Traumatol 1991;7(2):69-72.

21. ReinholdtJ, AndreasenJO, Soder PO, Otteskog P, Dybdahl $\mathrm{R}$, Riis I. Cultivation of periodontal ligament fibroblasts on extracted monkey incisors. A histological study of three culturing methods. Int J Oral Surg 1977; (6):215-25.

22. Soder PO, Otteskog P, Andreasen JO, Modeer T. Effect of drying on viability of periodontal membrane. Scand J Dent Res 1977;(85):174-86. 